\title{
ORTHODOX ICON AND RELIGIOUS IMAGE. AN INTER-RELIGIOUS ANALYSIS
}

Ioan Emil JURCAN*

\begin{abstract}
This paper is a comparison between different religious icons, images or symbols. Such an approach is necessary in order to highlight the iconic depth of an authentic Christian theology. Every religion has, as a symbolic element, the idea of struggle and spiritual power, but Orthodoxy implies love and the anastasic meeting with God, rather than the force. I will present several symbols from Hinduism, Buddhism, Islam, Judaism, etc. In these symbols we will seek the common elements that can create a connection between these religions and the Christian world. The orthodox Icon has a line that exceeds any other non-Christian religious symbols. It is about the epectatic dimension that turns art into a ladder of Bethel, an ascent to the infinite Divine, which is not force, fecundity, or abundance, but primarily Love.
\end{abstract}

Keywords: Christianity, Islam, icon, image, Shinto, Hinduism

\section{Introduction}

The terms image and icon need a key element in their mutual relationship, namely the term man. It does not necessarily mean man as an individual, but especially man in his connection with God. Man becomes an image, but he can also achieve the tendency towards the icon. $\mathrm{He}$ is an image through creation, but his purpose is to become an icon. The world is therefore based on images, but these images have as a result the path towards the iconic state, towards the state of holiness. The equation icon-image mainly applies to the man with transcendental tendencies, the man in search of the sacred and of holiness. In any religious cult, man needs the sacred image, that is why there are no

PhD, Professor, "1 Decembrie 1918" University of Alba Iulia (Faculty of Orthodox Theology), Alba Iulia, Romania. 
religious beliefs without having sacred, imagistic landmarks. The sun is an almost universal image in all pre-Christian religions, and even after Christ. Why was the sun chosen as a sacred image or icon of the divine? Before answering, we must say that we find the sun as a landmark in almost every religion of the world. In some of them it is even the supreme deity of heaven, the reference point of any cult.

\section{The Sun as an Icon in different religions. Egyptian Religions}

We will take as an example the faith of the Egyptians. The fortytwo districts had the same cult: the cult of the sun. Whether it was called Atum or Aton or Ra or any other collateral name, it was the same: the sun. Not necessarily the solar celestial body, but especially the idea of life derived from the sun was the condition that made this star to be the religious landmark of the Egyptians. The Egyptians knew very well that where the sun rises and where the light is, there is life. The opposite of the sun, of light, and of vegetation, means desert, dryness, darkness and death. Thus, the fact that the shore of the Nile, flooded and penetrated by the sun's rays, was rendered very fertile for agriculture, and gave two grain crops per year and other vegetables needed for life, made the Egyptians dependent on the cult of the sun. The Pharaoh, in his conflict with Moses, also receives as a punishment, among the ten wounds, the darkening of the sun. An eclipse that lasts a few days defies scientific explanation of such a phenomenon and creates panic among the Egyptians and the Pharaoh's court. When the sun does not appear for a few days, the religious system of Egypt falls, because Ra is the reference center of the cult, and the Pharaoh is Ra's son. When Ra no longer shows his face, God is gone, God is no longer, or no longer wants to be the God of Egypt. And immediately the Pharaoh promises to let the people go out of the country, obviously to the country where milk and honey flow, Canaan.

\section{The Image in Precolumbian Civilization}

Another civilization related to the cult of the sun is the preColumbian one: the Mayan and the Azteca, but also the Inca. In these religious cultures the sun is also vital. The people depend on the sun and, as such, they create a mythology of their need for the sun to emerge from 
ARS LITURGICA. From the Image of Glory to the Immages of the Idols of Modernity

its weakness during winter and to become strong and fertilize the earth. The sacrifices of the hearts, that were being performed daily, through the pulse of the heart pulled out of the chest, helped to push the sun on the circumference of the sky, and as such, people felt the blessing of this god. Almost all the temples were east-west oriented, precisely to capture the sun's circuit on the circumference of the sky, and to accomplish this cult in the complexity of the daily life. In the Aztec culture, the sacrifice of the heart to the sun was a normal practice, which made the Spanish conquistadors unable to accept such a cruel society that naturally kills hundreds and thousands of people for just a few pulses that were considered the driving force that pushes the sun into the sky.

\section{Shintoism and Image}

Below, I would like to take some religious symbols of other religions, to compare them semantically and in depth with the Christian ones. Having this path, I wanted to capture some of the symbolic elements of the Far East, then to get closer to the Christian European world. For the Japanese world, the sun is the central symbol, represented under the name of the goddess Amaterasu ${ }^{1}$. The royal family is believed to descend from this goddess, a fact which gives it a maximum priority in Japanese society. The Japanese defeat in World War II lessened this cult of royalty. And yet, these three elements (the comb, the mirror and the sword) are considered to be the three things received by the royal house from Amaterasu. The symbolic religion of Japan defines the boundaries between the sphere of the sacred and the profane. The entrance into the sacred world is done through a delimitation: it is that tori gate or the sacred rope that breaks the world. The world, for this faith, is one that must be continually purified of evil spirits. For this purpose, a kind of whiplash is used to rid the evil, which leads more to an empathetic magic and less to spiritual depth. This is the onus. The space is thus bounded between the sacred (the world of kami) and the profane (the world of demons), and kannushi (the Shintoist priests) are the ones who delimit this world. The samurai society, the bushido code, the kamikaze rule, the

${ }^{1}$ On this subject see J. Gordon Melton, Religious Celebrations. An Encyclopedia of Holidays, Festivals, Solemn Observances and Spiritual Commemorations, vol.I (A-K), Santa Barbara - Denver - Oxford, ABC CLIO, 2011, p. 492- 493. 
blind sacrifice for the hierarchical superior, all these elements create out of this civilization a spirituality of total obedience of sacred character. The simplicity of the temples and the harmony in that space is complemented by the total obedience to the rule of law, considered as coming from the goddess Amaterasu.

\section{Cult of Image in Hinduism}

In the Hindu world, the religious symbol has another valence, because the religious thinking emphasizes the world's cyclicality and reincarnation. Here we find as symbolic and iconic element, highly appreciated by the Hindus, the famous dance of Nataraja representing the world in relation to the god Shiva. Everything is supposed to be a sacred dance, in which the god dances on the head of the Apasmara demon, symbolizing ignorance, within a circle of fire (the symbol of cyclicality and reincarnation). Shiva is the god of destruction in view of reconstruction, for through it the world is destroyed to create another cosmic cycle. The raised right hand symbolizes creation, while the left hand represents the destruction of the creation. The right hand lowered to the chest means protection, and the left-hand shows salvation. The world is the circle of fire, and the snake that cools it represents the energy (kundalini). Here as well the soteriological differences are insurmountable.

What Hinduism has in its terrifying iconography is the image of Shakti, which appears as a woman desiring blood, which brings death and reincarnation (Fig. 5). The gods of well-being and happiness sometimes have animal faces such as Ganesha (Fig. 6), or Hanuman, the monkey god (Fig. 7). What can we conclude in this speech? That there is a big difference about soteriology and human life in its earthly evolution towards the Christian faith. It is another perception of the idea of salvation and of relating to the divine.

\section{Image in Islam}

The Islamic world, which completely lacks symbols and images, still has some images that are considered part of the historical ensemble of Islam. If Muslims have eliminated from the Mosque any form of painting representing a human being or any kind of creature, they have 
ARS LITURGICA. From the Image of Glory to the Immages of the Idols of Modernity instead kept images defining this religion. It is the presence of the sword and the Qur'an, which has become the leitmotif of radicalism. It started from Muhammad's famous sword, which appears on some flags of Muslim countries (Fig. 8) ${ }^{2}$. This symbol became in time the characteristic of Islam, namely the idea of struggle, because the prophet of Islam practiced this kind of relationship with those who had another faith. Iran's Ayatollah Khomeini proclaimed: "Whatever good there is, it exists thanks to the sword and in the shadow of the sword! People cannot be made obedient except with the sword! The sword is the key to paradise, which can only be opened to holy warriors"3.

Even if some modifications have been brought, meaning the Kalashnikov has appeared instead of the sword, the image of the Quranweapon has remained. In the figures below we can clearly see this symbolic image (Fig. 9-15), in which everything seems to be a struggle or a preparation for struggle. It is true that Islam was imposed not by persuasion but by fighting. The world was divided into two parts: the world or home of Islam (Dar al-Islam) and the war house (Dar al-Harb). If some understanding was occasionally shown to Christians and Jews, because they were considered people of the book (Al Kitab), there was no understanding for the other religions. In Qur'an, Mahomed tells the fighters that they must ask those of other faiths to convert to Islam. If they refuse, they will be attacked and either killed or converted by force. Yet, Christians and Jews were only spared temporarily for their natural conversion to Islam. If they did not, they were transformed into possible financial slaves, who had to support the Islamic society through jizya. They were considered inferior citizens to Muslims, unable to wear the same clothes or enter Islamic society.

"Dhimmi (...) is a second-class citizen. If tolerated, it is for spiritual reasons, because the hope to convert him is preserved, and for material

${ }^{2}$ Prophet Muhammad hat 9 swords and this symbolizes his war mentality. Eight of nine swords are in Istanbul, in the Topkapi Palace and the 9th is in Cairo. See also Tom Holland, In the Shadow of the sword: The Birth of Islam and the Rise of the Global Arab Empire, New York - London - Toronto, Anchor Publisher, 2013; M.J. AKBAR,The Shade of Swords. Jihad and the conflict between Islam and Christianity, London - New York, Routledge, 2002.

${ }^{3}$ Lawrence Wright, The Looming Tower: Al Qaeda's Road to 9/11, London, Penguin Press, 2007, p. 47. 
reasons, because we impose him almost all fiscal charges. He is allowed a place to live in the city, but not without ever reminding him of his inferiority (...). The Dhimmi is not at all equal with the Muslim. He is oppressed by social inequality and is a despised caste; Inequality of individual rights; Inequality in the payment of taxes; Inequality to justice, because his testimony is not admitted by Muslim courts, and because in case of equal crimes he does not enjoy equality of punishment." 4

Omar's pact is clear in this respect. Below we can observe what the oath of Christians in front of Islam looks like:

"In the name of God, the Merciful and Compassionate. This is a letter to the servant of God Umar [ibn al-Khattab], Commander of the Faithful, from the Christians of such-and-such a city. When you came against us, we asked you for safe-conduct (aman) for ourselves, our descendants, our property, and the people of our community, and we undertook the following obligations toward you:

- We shall not build, in our cities or in their neighborhood, new monasteries, Churches, convents, or monks' cells, nor shall we repair, by day or by night, such of them as fall in ruins or are situated in the quarters of the Muslims.

- We shall keep our gates wide open for passersby and travelers. We shall give board and lodging to all Muslims who pass our way for three days.

- We shall not give shelter in our churches or in our dwellings to any spy, nor hide him from the Muslims.

- We shall not teach the Qur'an to our children.

- We shall not manifest our religion publicly, nor convert anyone to it. We shall not prevent any of our kin from entering Islam if they wish it.

- We shall show respect toward the Muslims, and we shall rise from our seats when they wish to sit.

- We shall not seek to resemble the Muslims by imitating any of their garments, the qalansuwa, the turban, footwear, or the parting of the hair. We shall not speak as they do, nor shall we adopt their kunyas.

- We shall not mount on saddles, nor shall we gird swords, nor bear any kind of arms nor carry them on our persons.

- We shall not engrave Arabic inscriptions on our seals.

${ }^{4}$ https://ro.wikipedia.org/wiki/Legământul_lui_Omar (accessed 26.04.2017). 
- We shall not sell fermented drinks.

- We shall clip the fronts of our heads.

- We shall always dress in the same way wherever we may be, and we shall bind the zunar round our waists

- We shall not display our crosses or our books in the roads or markets of the Muslims. We shall use only clappers in our churches very softly. We shall not raise our voices when following our dead. We shall not show lights on any of the roads of the Muslims or in their markets. We shall not bury our dead near the Muslims.

- We shall not take slaves who have been allotted to Muslims.

- We shall not build houses overtopping the houses of the Muslims.

- (When I brought the letter to Umar, may God be pleased with him, he added, "We shall not strike a Muslim.").

We accept these conditions for ourselves and for the people of our community, and in return we receive safe-conduct.

If we in any way violate these undertakings for which we ourselves stand surety, we forfeit our covenant [dhimma], and we become liable to the penalties for contumacy and sedition." 5

This mentality was taken over by the unleashed Islam after the Arab Spring in North Africa and Asia, applying the requirements of the Medina Constitution and the Omar Pact. The Islamic mentality is trying to create an Islamic state today as in the great caliphat period. In other words, the Asian and African national states are artificial geographic divisions, because there is only one Islamic community or umma that should speak the same language: Arabic. Also, Islamic pressure is manifested everywhere. "Partly because of the primacy of the word in Islam, and partly because of the religion's aversion to iconolatry and thus the figural arts, calligraphy has become the supreme artistic expression in the Muslim world. Yet Islamic calligraphy is more than just an art form; it is the visual representation of the eternal Quran, the symbol of God's living presence on earth"6.

${ }^{5}$ Al-Turtushi/Siraj al-Muluk, p. 229-230, apud Jacob Rader Marcus, The Jew in the Medieval World: A Source Book, 315-1791, Hebrew Union College Press, 1999, p. 1416.

${ }^{6}$ Reza Aslan, No god but God. The Origins, Evolution and Future of Islam, New York, Random House, 2005, p. 159. 
Below we can read the famous Medina ${ }^{7}$ Constitution, through which the oppression of the Judeo-Christian world began.

"In the name of God the Compassionate, the Merciful.

- This is a document from Muhammad the prophet (governing the relations) between the believers and Muslims of Quraysh and Yathrib, and those who followed them and joined them and labored with them.

- They are one community (umma) to the exclusion of all men.

- The Quraysh emigrants according to their present custom shall pay the bloodwit within their number and shall redeem their prisoners with the kindness and justice common among believers.

- (4-8) The B. 'Auf according to their present custom shall pay the bloodwit they paid in heatheism; every section shall redeem its prisoners with the kindness and justice common among believers. The B. Saida, the B. '1-Harith, and the B. Jusham, and the B. al-Najjar likewise.

- (9-11) The B. 'Amr b. 'Auf, the B. al-Nabit and the B. al-'Aus likewise.

- (12)(a) Believers shall not leave anyone destitute among them by not paying his redemption money or bloodwit in kindness.

- (12)(b) A believer shall not take as an ally the freed man of another Muslim against him.

- (13) The God-fearing believers shall be against the rebellious or him who seeks to spread injustice, or sin or animosity, or corruption between believers; the hand of every man shall be against him even if he be a son of one of them.

- (14) A believer shall not slay a believer for the sake of an unbeliever, nor shall he aid an unbeliever against a believer.

- (15) God's protection is one, the least of them may give protection to a stranger on their behalf. Believers are friends one to the other to the exclusion of outsiders.

- (16) To the Jew who follows us belong help and equality. He shall not be wronged nor shall his enemies be aided.

- (17) The peace of the believers is indivisible. No separate peace shall be made when believers are fighting in the way of God. Conditions must be fair and equitable to all.

- (18) In every foray a rider must take another behind him.

${ }^{7}$ Apud A. Guillaume, The Life of Muhammad - A Translation of Ishaq's Sirat Rasul Allah, Oxford University Press, Karachi, 1955, p. 231-233. 
- (19) The believers must avenge the blood of one another shed in the way of God.

- (20)(a) The God-fearing believers enjoy the best and most upright guidance.

- (20)(b) No polytheist shall take the property of person of Quraysh under his protection, nor shall he intervene against a believer.

- (21) Whoever is convicted of killing a believer without good reason shall be subject to retaliation unless the next of kin is satisfied (with blood-money), and the believers shall be against him as one man, and they are bound to take action against him.

- (22) It shall not be lawful to a believer who holds by what is in this document and believes in God and the last day to help an evil-doer or to shelter him. The curse of God and His anger on the day of resurrection will be upon him if he does, and neither repentance nor ransom will be received from him.

- (23) Whenever you differ about a matter it must be referred to God and to Muhammad.

- (24) The Jews shall contribute to the cost of war so long as they are fighting alongside the believers.

- (25) The Jews of the B. 'Auf are one community with the believers (the Jews have their religion and the Muslims have theirs), their freed men and their persons except those who behave unjustly and sinfully, for they hurt but themselves and their families.

- (26-35) The same applies to the Jews of the B. al-Najjar, B. al-Harith, B. Saiida, B. Jusham, B. al-Aus, B. Tha'laba, and the Jafna, a clan of the Tha'laba and the B. al-Shutayba. Loyalty is a protection against treachery. The freedmen of Tha'laba are as themselves. The close friends of the Jews are as themselves.

- (36) None of them shall go out to war save the permission of Muhammad, but he shall not be prevented from taking revenge for a wound. He who slays a man without warning slays himself and his household, unless it be one who has wronged him, for God will accept that.

- (37) The Jews must bear their expenses and the Muslims their expenses. Each must help the other against anyone who attacks the people of this document. They must seek mutual advice and consultation, and loyalty is a protection against treachery. A man is not liable for his ally's misdeeds. The wronged must be helped.

- (38) The Jews must pay with the believers so long as war lasts.

- (39) Yathrib shall be a sanctuary for the people of this document. 
- (40) A stranger under protection shall be as his host doing no harm and committing no crime.

- (41) A woman shall only be given protection with the consent of her family.

- (42) If any dispute or controversy likely to cause trouble should arise it must be referred to God and to Muhammad the apostle of God. God accepts what is nearest to piety and goodness in this document.

- (43) Quraysh and their helpers shall not be given protection.

- (44) The contracting parties are bound to help one another against any attack on Yathrib.

- (45)(a) If they are called to make peace and maintain it they must do so; and if they make a similar demand on the Muslims it must be carried out except in the case of a holy war.

- (45)(b) Every one shall have his portion from the side to which he belongs.

- (46) The Jews of al-Aus, their freedmen and themselves have the same standing with the people of this document in purely loyalty from the people of this document. Loyalty is a protection against treachery. He who acquires ought acquires it for himself. God approves of this document.

- (47) This deed will not protect the unjust and the sinner. The man who goes forth to fight and the man who stays at home in the city is safe unless he has been unjust and sinned. God is the protector of the good and God-fearing man and Muhammad is the apostle of God.

(The Medina Charter, 622 C.E.)

The iconic interpretation is therefore substituted in Islam by symbols that either have a neutral connotation (floral decorations), or a message (religious expressions) or battle (the sword with the Qur'an), which demonstrates the missionary way totally different from the Christian one, where preaching and conviction through moral life is the only possibility to communicate the revealed truth and to draw to Christ. "The issue of whether or not a particular religious tradition like Catholicism or Eastern Orthodox Christianity or Islam is compatible with democracy is part of another era of political history"s.

8 John L. Esposito/Tamara Sonn / John Voll, Islam and Democracy after the Arab Spring, New York, Oxford University Press, 1996, p. 235. 


\section{The Icon in Judaism}

For the Jewish world, the image is also quite limited as expressiveness, relying rather on symbols. The Jews had the Temple in Jerusalem $^{9}$ as the first symbol, where the cherubim angels were guarding the Holy of Holies and the Ark of the Law or the Ark of the Covenant. Losing this spiritual treasure, the symbolic images of the Jews remained fairly restricted. Thus we can speak of the synagogue, as a meeting space, an image of the temple after its destruction. Menorah (Fig. 16) is the symbol of the divine light, received in the temple of Solomon's times. $\operatorname{Kippah}^{10}$ (Fig. 17) is the coverage of man with divine glory, and the one who bears it always lives the feeling that God's palm is above his head. The same sense of protection is enjoyed by the Jew, when he places the mezuzah ${ }^{11}$ on the doorframe (Fig. 18), which represents the protection in front of the angel of death in Egypt, who killed all the firstborn of this country one night. The sacred images are quite a lot, if one were to remember the tallit (Fig. 19) and the other religious clothing elements (tzitzit $^{12}$ Fig. 20, filacter ${ }^{13}$ Fig. 21) that all symbolically speak of the divine protection and the presence of God in the life of the Jew.

\section{The Message of the Christian Icon}

Finally, for the Christian theology, things are quite different. The iconic presence in Orthodox Christianity is not a symbolic but a real one. God is not just a symbol of my Christian faith, but a reality that I feel, see

${ }^{9}$ See John M. Lundquist, Temple of Jerusalem. Past, present and future, Praeger, 2008. He says: "One could say that Jerusalem and its Temple stand at the center of history, past, present, and future. If one counters that the drama of the Jerusalem story is little known in the vast hinterlands of Asia, and that the events that have roiled the Middle East and the West for approximately the last 3000 years create barely a ripple in further Asia, we could say that the power of the apocalyptic visions that surround Jerusalem and its Temple is such that it can engulf the rest of a world that is otherwise dismayed at the intimate entanglement of a religious apocalyptic vision with the brutal realities of contemporary politics" (p. 231).

${ }^{10}$ See Frank A. Salamone (ed), Encyclopedia of religious Rites, Rituals and Festivals, New York - London, Routledge, 2004, p. 204.

${ }^{11}$ Ibidem, p. 375 - 378.

${ }^{12}$ Sara E. KARESH and Mitchell M. HuRvitz, Encyclopedia of Judaism, New York, Fact on File Publisher, 2006, p. 187.

${ }^{13}$ Ibidem, p. 513. 
and talk with in a real way. The icon is the gracious presence through the image that communicates with God as if we were face to face. There is no trace of violence or hardness in the Orthodox icon, but at most of maturity. Christ (Fig. 22), even in the image of the infant, proves divine maturity, which blesses the whole creation with the liturgical gifts.

Another element that transposes from the revelation of the icon is the state of astonishment which it emanates. In the true Orthodox icon there is a permanent wonder in front of the ineffable divine. The new state of astonishment is also called enthusiasm, which consists of two words $($ en + theosis), showing the relationship between man and God. In the Orthodox icon only a holy thrill and not a terror appears, and the idea of a weapon, as it appears in the icons with military martyrs, does not define the martyr's fighter's status, but his profession (soldier) before assuming his death as a martyr.

There is still one more criterion of the authentic icon, the one of the gracious transposition. An icon without the presence of grace is just a religious picture. The icon conveys not only the man's view on the eighth day, but also the outpouring of grace over the man who tends towards this day of the eschaton. "Theophany, says C. A. Tsakiridou, is ontophany and anthropophany. What the ascetic sees can be seen by others whose senses have been restored - those who like the disciples on Mount Tabor have witnessed her deification"14.

\section{Conclusions}

In conclusion, I do not think there can be any imagistic similarity except a tangential one between the Christian icon and the iconic representations of other religions, since many of the criteria underlying the icon as an icon are missing. Without these elements, to which the presence of the divine grace is added, the icon is at most a picture or a picture of sacred connotation. The world, however, needs icons, because they are the models of an authentic life. Without the icon we no longer have landmarks, and their absence makes man manipulative and disoriented. In the consumer society that devours the image and is dependent on it, the icon appears as a landmark of the transcendental

${ }^{14}$ C. A. TSAKIRIDOU, Orthodox Theology and the Aesthetics of the Christian Image, Farnham (England) - Burlington (U.S.A.), ASHGATE, 2013, p. 252. 
ARS LITURGICA. From the Image of Glory to the Immages of the Idols of Modernity image that gives meaning to the immanent. Its presence makes sense to the whole image, for it guides it towards the eighth day, the day of eternity.

\section{References}

1. AKBAR, M.J., The Shade of Swords. Jihad and the conflict between Islam and Christianity, London - New York, Routledge, 2002.

2. Aslan, Reza, No god but God. The Origins, Evolution and Future of Islam, New York, Random House, 2005.

3. EsPosito, John L., Tamara Sonn and John Voll, Islam and Democracy after the Arab Spring, New York, Oxford University Press, 1996.

4. Guillaume, A., The Life of Muhammad - A Translation of Ishaq's Sirat Rasul Allah, Oxford University Press, Karachi, 1955.

5. Holland, Tom, In the Shadow of the sword: The Birth of Islam and the Rise of the Global Arab Empire, New York - London - Toronto, Anchor Publisher, 2013.

6. KARESH, Sara E./ HuRVITZ, Mitchell M., Encyclopedia of Judaism, New York, Fact on File Publisher, 2006.

7. LundQuist, John M., Temple of Jerusalem. Past, present and future, Praeger, 2008.

8. MARCUS, Jacob Rader, The Jew in the Medieval World: A Source Book, 315-1791, Hebrew Union College Press, 1999.

9. Melton, J. Gordon, Religious Celebrations. An Encyclopedia of Holidays, Festivals, Solemn Observances and Spiritual Commemorations, vol. I (A-K), Santa Barbara - Denver - Oxford, ABC CLIO, 2011.

10. Nellas, Panayotis, Omul-animal îndumnezeit. Perspective pentru o antropologie ortodoxă (The man - a deified animal. Perspectives for an orthodox anthropology), introd. study and transl. by deac. Ioan I. ICĂ jr., Sibiu, Deisis, 2009.

11. PUHALO, Lazăr, Icoana ca Scriptură (The Icon as Scripture), Romanian, transl. by M.Rădulescu, Oradea, Theosis, 2009.

12. SAlamone, Frank A. (ed.), Encyclopedia of religious Rites, Rituals and Festivals, New York - London, Routledge, 2004.

13. St. John DAMASCENE, Cele trei tratate contra iconoclaştilor (Apology Against Those who Decry Holy Images), Romanian transl. introd. and 

notes by Dumitru Fecioru, București, IBMBO, 2016.

14. TSAKIRIDOU, C. A., Orthodox Theology and the Aesthetics of the Christian Image, Farnham (England) - Burlington (U.S.A.) ASHGATE, 2013.

15. USPENSKY, Leonid, Teologia icoanei în Biserica Ortodoxă (The theology of icon in the Orthodox Church),introd. study and Romanian transl. by Teodor Baconsky, București, Anastasia, 1994.

16. VANCA, Dumitru, Icoană și Cateheză (Icon and Catechesis), Alba Iulia, Reîntregirea, 2005.

17. Wright, Lawrence, The Looming Tower: Al Qaeda's Road to 9/11, London, Penguin Press, 2007. 


\section{LIST OF IMAGES}

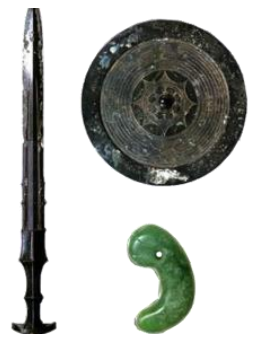

Fig. 1

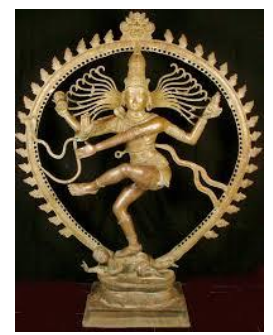

Fig. 4

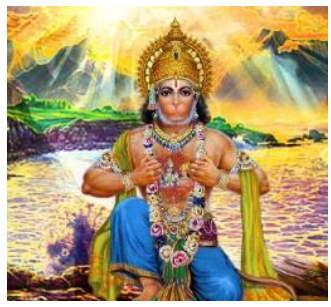

Fig. 7

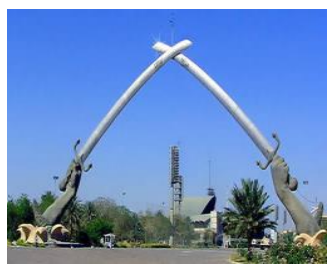

Fig. 10

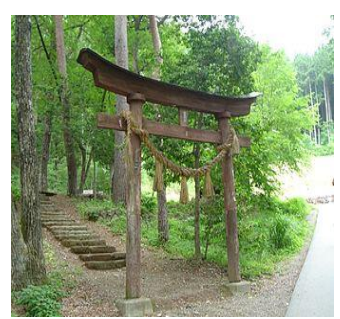

Fig. 2

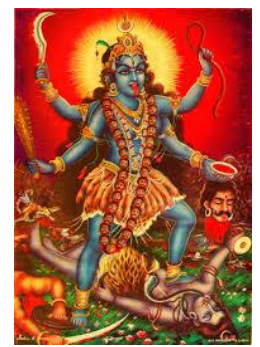

Fig. 5

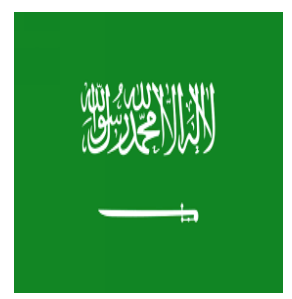

Fig. 8

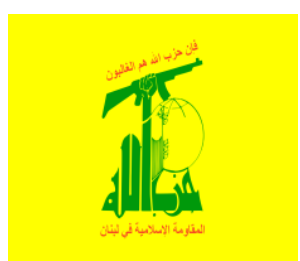

Fig. 11

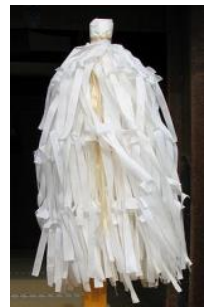

Fig. 3

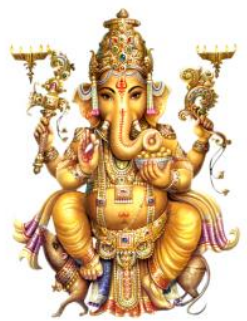

Fig. 6

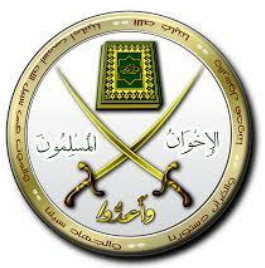

Fig. 9

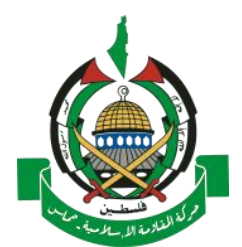

Fig. 12 


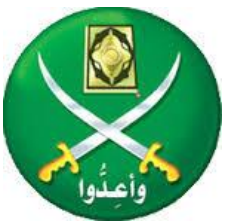

Fig. 13

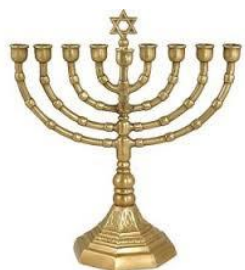

Fig. 16

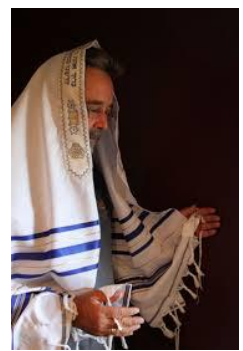

Fig. 19

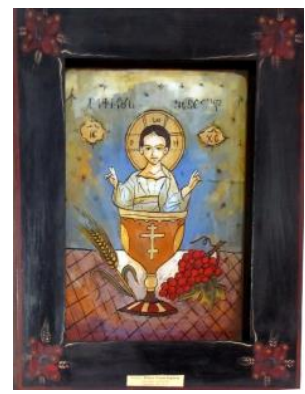

Fig. 22

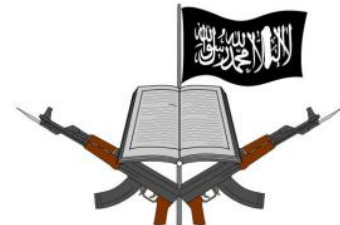

Fig. 14

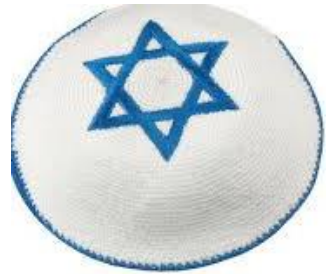

Fig. 17

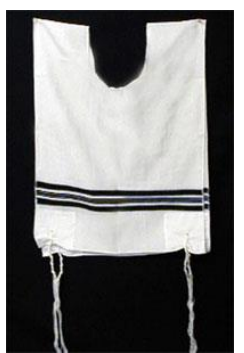

Fig. 20

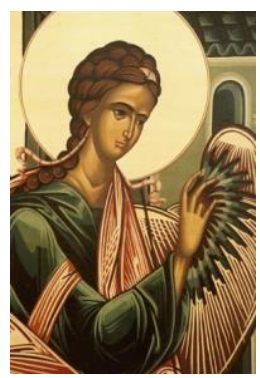

Fig. 23

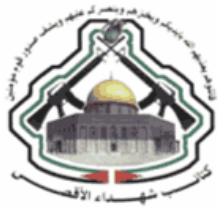

Fig. 15

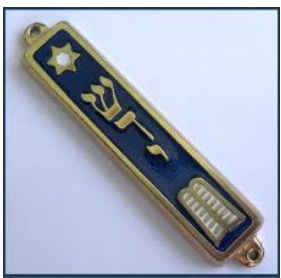

Fig. 18

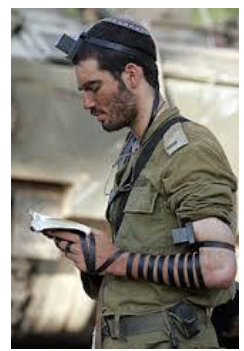

Fig. 21

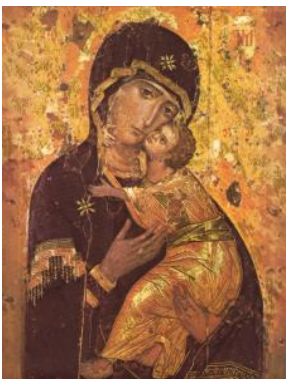

Fig. 24 